\title{
$\mathrm{CFD}$ 를 이용한 패들교반속도에 따른 속도경사 및 총물질전달시간 산정
}

\author{
전항배 ${ }^{\dagger}$ - 전동걸 · 홍기원 ${ }^{*}$ - 한홍식 ${ }^{*}$ 박병창** \\ 충북대학교 환경공학과 \\ (주)에스티아이 C\&D \\ **삼성디스플레이
}

\section{Evaluation of Local Velocity Gradient and Total Mass transfer Time at Various Rotating Velocity by Using Computational Fluid Dynamics}

\author{
Hang-Bae Jun ${ }^{\dagger} \cdot$ Dong-Jie Tian $\cdot$ Ki-Won Hong ${ }^{*} \cdot$ Hong-Sig Han ${ }^{*} \cdot$ Byeong-Chang Park ${ }^{* *}$ \\ Department of Environmental Engineering, Chungbuk National University, 12 Kaeshin dong Cheongju, Chungbuk, Korea, 361-763 \\ "STI Connect \& Development, B-301 woolim Lion's Valley, 371-28 Gasan-Dong Geumcheon-Gu Seoul, Korea, 153-786 \\ ${ }^{* *}$ SAMSUNG Display Environment Safety \\ (Received 5 August 2013, Revised 18 February 2014, Accepted 21 February 2014)
}

\begin{abstract}
Velocity gradient, G, a measure of the average velocity gradient in the fluid has been applied for complete mixing of chemicals in mechanical mixing devices. G values were calculated by the power input transferred to fluid in turbulent and transient range. Chemical reactions occur so fast that total mass transfer time required for even distribution of the chemicals determine the overall reaction time. The total mass transfer time is composed of the time for complete mixing through the reactor and for diffusion of the chemicals into the eddy. Complete mixing time was calculated by CFD (computer fluid dynamics) and evaluated by tracer tests in 2 liter jars at different rotating speeds. Turbulent range, Reynolds number above 10,000 in regular 2 liter jars occurred at revolution speed above $100 \mathrm{rpm}$ (revolution per minute), while laminar range occurred at revolution speed below $10 \mathrm{rpm}$. A typical range of rotating speed used in jar tests for water and wastewater treatment was between 10 and 300 rpm, which covered both transient and turbulent range. G values supplied from a commercial jar test apparatus showed big difference from those calculated with power number specially in turbulent range. Diffusion time through eddy decreased 1.5 power-law of rotating speed. Complete mixing time determined by pumping number decreased increases in rotating speed. Total mass transfer time, finally, decreases as rotating speed increases, and it becomes $1 \mathrm{sec}$ at rotating speed of 1,000 rpm. Complete mixing times evaluated from tracer tests showed higher than those calculated by power number at higher rotating speed. Complete mixing times, however, calculated by CFD showed similar to those of experimentally evaluated ones.
\end{abstract}

Key words : CFD, Complete mixing time, Diffusion time, G value, Mass transfer time, Velocity gradient

\section{Introduction}

급속혼화공정은 짧은 시간 내에 반응물질을 서로 접촉시켜 목표로 하는 화학반응을 유도하는 공정으로 반응시간 내에 주입한 화학약품이 균일하게 혼합될 수 있도록 충분히 큰 교반속도로 교반해 주고 있다. 급속혼화공정의 혼화도에 따 라 플록형성지와 침전지에 미치는 영향 등을 고려해 볼 때 급속혼화공정은 수처리 공정에서 매우 중요한 역할과 비중 을 차지하게 된다. 반응조로 투입되는 금속염의 응집제의 경우 1 초 이내에 가수분해되면서 수중의 콜로이드입자와 순간적으로 흡착이 이루어지기 때문에 강한 교반강도를 통 해 가능한 짧은 시간내에 완전혼합이 이루어지는 것이 바람 직한 것으로 알려져 있다(Jung et al, 2003). 즉, Aluminium

\footnotetext{
${ }^{\dagger}$ To whom correspondence should be addressed.

jhbcbe@cbnu.ac.kr
}

의 경우 Aluminium은 수화하면서 초기에 $\mathrm{Al}(\mathrm{OH})_{2}{ }^{+}$와 같은 monomer가 되고, 시간이 경과함에 따라 여러 종류의 중간 생성물을 생성하게 되며, 이러한 monomer 및 중간생성물 은 다가의 양이온성 알루미늄 수화물로 (-)로 하전된 탁도 물질이나 humic 물질 등을 효과적으로 불안정화를 유발시 키는 것으로 알려져 있다고 한다(Jung et al., 2006). 그러나 이러한 중간생성 수화물들은 매우 짧은 시간동안 $\left(10^{-4} \sim 1 \mathrm{sec}\right)$ 체류하여 짧은 시간 내의 고강도의 교반을 필요로 한다.

화학약품의 반응시간은 매우 짧기 때문에 화학약품을 반 응조 내에 균일하게 확산시키는 데 필요한 총물질전달시간 이 반응기 내 체류시간을 결정한다. 총물질전달시간은 화학 약품이 완전히 혼합되는 완전혼합시간과 eddy 내로 확산해 들어가는 물질확산시간의 합으로 산정할 수 있다. 전통적으 로 교반속도는 유체부피에 가해지는 동력으로부터 유도한 속도경사, $\mathrm{G}$ 값을 사용해 오고 있다. 속도경사, $\mathrm{G}(\mathrm{du} / \mathrm{dy})$ 값 은 정수공정에서 급속 및 완속공정 설계 및 운전기준으로 
사용되어 왔으나, $\mathrm{G}$ 값은 층류조건에서 반응조 부피에 대 한 입력동력의 기하학적 평균값으로 정의되기 때문에 난류 상태로 운영하는 급속교반공정 해석에 부적합하다고 지적 하고 있다(Camp, 1968). Han and Lawler (1992)은 입자의 크기에 따라 $\mathrm{G}$ 값의 적용을 달리해야 하는데, 입자의 크기 가 $1 \mu \mathrm{m}$ 이상의 입자에서는 $\mathrm{G}$ 값이 의미가 있지만, 그 이 하의 작은 입자들은 Brownian 분산에 의해, 침전성이 있는 더 큰 입자들은 속도차 침전에 의해 입자들이 충돌하기 때 문에 이를 $\mathrm{G}$ 값으로 해석하는 것은 문제가 있다고 하였다.

화학반응이 빠르게 진행되는 산화나 응집(coagulation)의 경우 짧은 시간 내에 응집제와 반응물질(수중의 콜로이드 및 부유물질)이 접촉할 수 있도록 강하게 교반해 주는 것 을 권장하고 있다(Hudson and Wolfner, 1967; Kawamura, 1976; Vrale and Jorden, 1971). 이는 급속혼화의 강도가 강 할 경우에는 단일성(monomer) 산물이 주로 생성되는 반면, 강도가 약할 경우에는 복합성(polymer) 산물이 주로 생성되 기 때문이다(Kim et al., 2011). 교반공정은 반응조와 교반 기로 구성되어 있고, 화학약품의 반응속도에 따라 반응조의 수리학적 체류시간 $(\tau)$, 교반장치의 펌핑능력 및 동력을 결 정해 주어야 한다. 교반장치의 특성 및 설계에 관여하는 인자는 완전 난류영역에서 펌핑수와 동력수 등이 있다. 반 응조의 난류영역은 레이놀드수 $\left(R_{e}\right)$ 가 10,000 이상이다.

$N_{Q}=\frac{Q}{N D^{3}}$

$N_{P}=\frac{P}{\rho N^{3} D^{5}}$

$R_{e}=\frac{D^{2} N \rho}{\mu}$

$N_{Q}=$ pumping number

$N_{P}=$ power number

$Q=$ flowrate, $\mathrm{m}^{3} / \mathrm{s}$

$P=$ power input, $\mathrm{kg} \cdot \mathrm{m}^{2} / \mathrm{s}^{3}$

$N=$ rotating speed per second, rps

$D=$ diameter of impella, $\mathrm{m}$

$\rho=$ density of water, $\mathrm{kg} / \mathrm{m}^{3}$

$\mu=$ viscocity of water, $\mathrm{N} \cdot \mathrm{s} / \mathrm{m}^{2}$

화학반응은 화학약품과 반응물질이 서로 접촉해야 진행 되기 때문에 혼합과정에서도 일부 상호 접촉이 이루어 질 수는 있지만, 완전혼합 후에 반응이 진행된다고 가정할 수 있다. 그러므로 완전혼합시간 $\left(t_{M}\right)$ 은 수리학적 체류시간과는 그 의미가 다르며, 주입한 화학약품이 반응조내에 균일하게 완전히 혼합되는 시간으로 정의할 수 있다. 완전혼합시간은 추적자(tracer)를 주입하여 추적자의 농도가 반응조 내에 일 정하게 되는 시간을 측정하여 결정할 수 있다. 완전혼합시 간은 반응조의 크기와 임펠라의 펌핑용량에 따라 결정되며, 식 (1)과 같이 임펠라의 직경과 회전수가 중요한 변수이다.
펌핑수는 대부분 상용되는 임펠라의 경우 그 형상 및 종류 에 따라 제공되고 있다. 임펠라의 회전에 의한 펌핑유량에 의해 결정되는 수리학적 시간 $(\mathrm{V} / \mathrm{Q})$ 을 순환시간(circulation time, $\left.t_{C}\right)$ 이라고 정의하면, 완전혼합시간은 순환시간의 약 2-3배가 된다(Amirtharajah et al., 1991).

$t_{C}=\frac{V}{Q}=\frac{V}{N_{Q} N D^{3}}$

$t_{M}=2 \sim 3 t_{C}$

$t_{M}=$ complete mixing time, sec

$t_{C}=$ circulation time, sec

교반으로 발생한 난류에 의해 eddy가 발생하고, 가장 작 은 eddy내로 확산에 의해 물질이 전달되는 확산시간은 다 음 식으로 표현될 수 있다.

$t_{d}=\frac{3 R^{2}}{4 D_{l}}$

여기에서

$t_{d}=$ time for molecules to diffuse in or out of eddy, $\mathrm{s}$

$R=$ radius of eddy, $\mathrm{m}$

$D_{l}=$ liquid diffusivity of chemical molecule $\left(\sim 10^{-9} \mathrm{~m}^{2} / \mathrm{s}\right)$

식 (6)의 물질확산시간은 확산계수 및 eddy 크기에 따라 결정되며, eddy의 평균크기는 Kolmogorov microscale, $n$ 의 2 배이므로 $\mathrm{R}=n$ 가 된다. Kolmogorov microscale, $n$ 는 다 음과 같이 속도경사 $\mathrm{G}$ 및 점성계수의 함수로 결정된다.

$\eta=\left(\frac{\nu^{3}}{\epsilon}\right)^{1 / 4}$

$\epsilon=\frac{P}{M}=\frac{P}{\rho V}=\nu \frac{P}{\mu V}=\nu G^{2}$

$\eta=\left(\frac{\nu}{\bar{G}}\right)^{1 / 2}$

$\bar{G}=\sqrt{\frac{P}{\mu V}}$

$\eta=$ Kolmogorov microscale, $\mathrm{m}$

$v=$ kinematic viscosity, $\mathrm{m}^{2} / \mathrm{s}$

$\mathcal{E}=$ energy dissipation per unit mass,

$M=$ mass of water, $\mathrm{kg} / \mathrm{m}^{3}$

$P=$ power input, $\mathrm{kg} \cdot \mathrm{m}^{2} / \mathrm{s}^{3}$

식 (9)를 식 (6)에 대입하여 정리하면 식 (11)과 같으며, 수온이 $10^{\circ} \mathrm{C}$ 를 가정하면, 그 값은 약 1,000 이 된다. 즉, 물 
질확산시간, $t_{d}$ 는 속도경사 $\mathrm{G}$ 에 의해 결정되는 값이며, $\mathrm{G}$ 가 $1,000 \mathrm{~s}^{-1}$ 일 경우 $t_{D}$ 는 약 $1 \mathrm{sec}$ 가 된다.

$G \cdot t_{D}=\frac{3 \nu}{4 D_{l}}=\frac{3 \times 1.31 \times 10^{-6} \mathrm{~m}^{2} / \mathrm{s}}{4 \times 10^{-9} \mathrm{~m}^{2} / \mathrm{s}}=982$

그러므로 화학약품이 투입 후 실질적으로 화학반응이 시 작되는 시간은 완전혼합시간과 물질확산시간(식 (5), (6))에 서 산출된 두 시간을 합한 값이 되며, 화학반응시간이 위 의 두 물리적인 시간보다 매우 작다고 가정할 경우 식 (12)의 총물질전달시간 $\left(t_{m t}\right)$ 을 반응기 내 체류시간으로 간주 할 수 있다.

$t_{m t}=t_{M}+t_{D}$

$t_{m t}=\frac{3 V}{N_{Q} N D^{3}}+\frac{3 \nu}{4 D_{l}}\left(\frac{\mu V}{\rho N_{p} N^{3} D^{5}}\right)^{1 / 2}$

결과적으로 식 (13)로 표현되는 반응시간, 즉 총물질전달 시간은 난류의 영역에서 교반장치의 펌핑수 및 동력수와 밀접한 관계가 있음을 알 수 있다.

기존의 연구에서는 $\mathrm{CFD}$ (computer fluid dynamic) 및 추 적자 실험을 통해 설계상의 최적 설계비율 및 수리학적 체 류시간 등을 산출하였으나 본 논문에서는 다양한 교반강도 에서 추적자를 이용하여 완전혼합시간을 측정하고, eddy로 의 물질전달시간을 계산하여 총물질전달시간을 산출하는 것을 연구의 목적으로 한다. 또한, $\mathrm{CFD}$ 를 이용하여 반응조 내 유체의 특성 및 총물질전달시간을 계산하여 급속교반조 나 기타 화학반응조의 설계 및 해석에 활용하고자 한다.

\section{Materials and Methods}

\section{1. 실험재료 및 장치}

실험에 사용한 반응조 및 교반장치는 Fig. 1 과 같이 일반 적으로 Jar test에 사용하는 2리터 용량의 사각형 Jar (Phips \& Bird Co.)이며, 편평한 2개의 날개로 구성된 임펠라가 구비되어 있다. 교반강도를 나타내는 속도경사, $\mathrm{G}$ 값은 동 사에서 제공하는 자료(Fig. 1)를 활용하였으며, 레이놀드수를 계산하여 적정 실험범위를 설정하였다. 실험에 사용한 시료 는 C 정수장 착수정에서 급속혼화조로 유입되는 원수를 사 용하였고, 추적자는 불소용액을 사용하였으며, 이에 따른 불소이온 분석은 이온 크로마토그래피(Ion Chromatography) 를 이용하여 수용성 $\mathrm{F}^{-}$이온을 측정하였다. 그리고 전산유 체역학 분석은 주식회사 에스티아이 $\mathrm{C} \& \mathrm{D}$ 에서 개발된 Water $\mathrm{CFD}$ 프로그램을 사용하였다.

\section{2. 실험방법}

추적자는 적정 강도로 교반되고 있는 반응조 수면위에 주입하였고, 주입과 동시에 반응조 하단에서 시료를 채취하 여 농도를 측정하였다. 시료의 농도값이 완전혼합 후 계산된

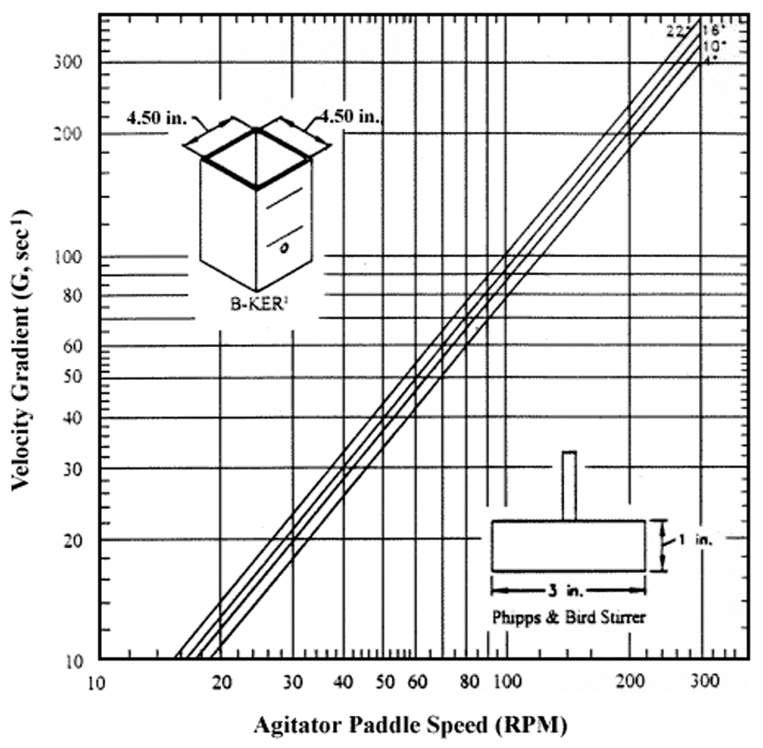

Fig. 1. A Phips \& Bird $2 \mathrm{~L}$ Jar and suggested $G$ values vs. rotating speed.

불소의 기준농도값을 초과하는 경우는 분석에서 제외시켰 으며, 측정된 불소농도가 일정한 기준농도값으로 수렵되어 10 초이상 유지될 경우 실험을 종료하였다.

Water $\mathrm{CFD}$ 를 이용하여 순환시간을 직접 산정하기 어렵 기 때문에 $2 \mathrm{~L} \mathrm{Jar}$ 에 물과 동일한 비중을 갖는 가상의 화학 약품을 $\mathrm{Jar}$ 수표면에 첨가하고, 입체적인 $\mathrm{Jar}$ 에서 교반시간 에 따라 추적자의 농도 $\left(C_{T}\right)$ 를 산정하였다. 완전혼합시간은 각 격자 내 추적자의 농도가 평형농도에 도달하기 직전의 시간으로 다음과 같이 산출하였다.

먼저 완전혼합시간 후 추적자의 평형농도는 식 (14)와 같다.

$\bar{C}=\frac{M_{T}}{V}$

$M_{T}$ : 추적자 질량, $\quad V:$ 유체의 총 용적

각 격자에서의 추적자의 농도를 평형농도로 나누어 표준 화(normalize)해 주면 다음과 같다.

$C_{N}=\frac{C_{T}}{\bar{C}}$

$C_{T}:$ 각 격자내 추적자 농도

완전혼합시간은 $\mathrm{Jar}$ 내 모든 격자에서 추적자의 표준농 도가 1 이 되는 바로 직전의 교반시간을 의미한다. 이를 $\mathrm{CFD}$ 로 계산하기 위하여 $\mathrm{Jar}$ 의 상하 8 지점의 표준농도 $\left(C_{N}\right)$ 의 평균값이 $1 \pm 0.001$ 이 되는 시간을 산출하여 결정하였다. 표준농도가 1.0 이 되는 시점을 정확하게 설정하기 어렵고, 완전혼합시간을 초과하여 산정할 가능성이 크기 때문에 표준농도에 $99.9 \%$ 도달하는 시점을 완전혼합시간으로 결 정하였다. 


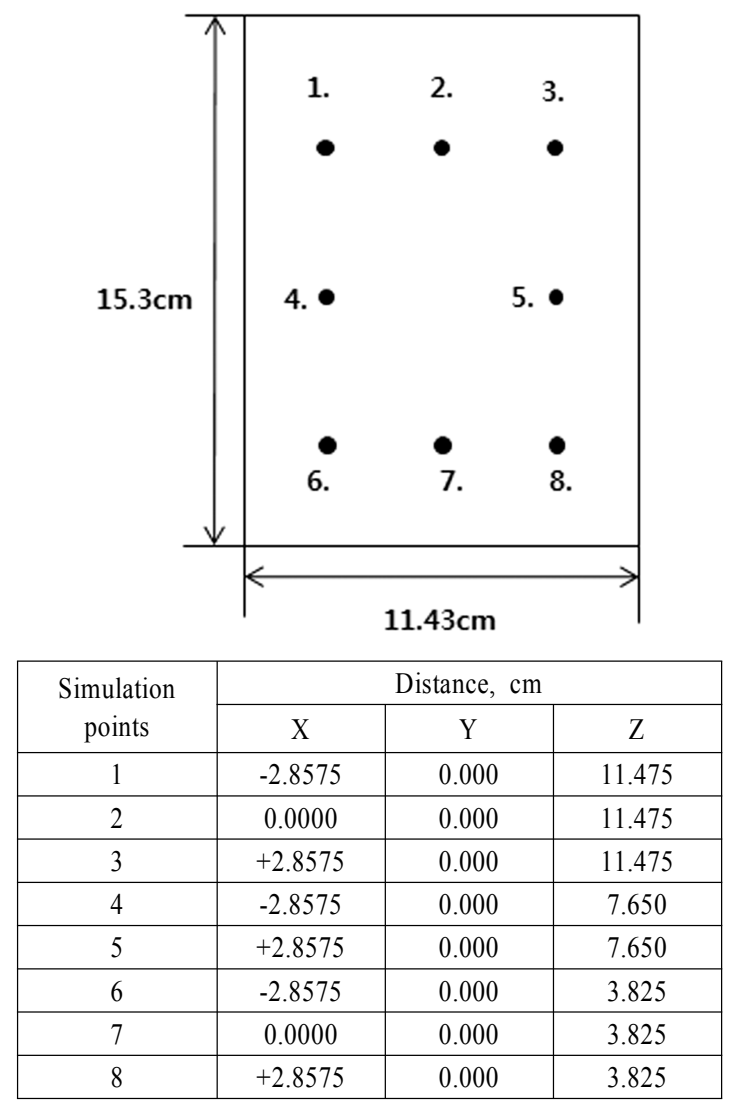

Fig. 2. Simulation points in the jar for evaluating tracer dispersion after addition to the surface using Water-CFD.

$t_{M}=$ time at $\left(C_{N}-1.0 \leq \pm 0.001\right)$

$\mathrm{CFD}$ 를 이용하여 Fig. 2와 같이 Jar의 수표면에 추적자(스 칼라)를 순간 주입한 후 일정한 회전속도로 교반하면서 교 반시간에 따라 추적자의 확산과정을 모의하여 완전혼합시 간을 산출하였다. 교반속도는 완속과 급속교반의 범위인 $50,100,200,400,600 \mathrm{rpm}$ 으로 변화시켜가며 모의하였으 며, 주입한 스칼라양은 1 로 하였다. 교반시간은 교반속도에 따라 충분한 확산이 이루어질 수 있도록 $0.0 \sim 19.5$ 초까지 하였고, 추적자 모의위치는 Fig. 2와 같이 Jar의 상중하 8 곳 으로 하였다. Fig. 2의 좌표는 Jar를 반으로 자른 종단면으로 중앙을 좌표의 중심점으로 한 각 point의 위치이다.

\section{3. 수치해석법}

물리량의 수치미분을 위하여 각 셀의 면에 위치한 국부 좌표계와 셀 중심에 위치한 국부좌표계를 Fig. 3과 Fig. 4 에 도시하였다. Fig. 3에는 면에 설정된 국부좌표계를 도시 하였는데, 실선으로 셀을 도시하였으며 면을 공유하는 인접 셀을 점선으로 도시하였다. 여기서 각 셀의 절점은 로 면의 중심은 $\bigcirc$ 로 셀의 중심은 $\square$ 로 도시하였다. 축은 두 셀의 중심점을 연결하는 방향으로 $\mathrm{n}$, $\zeta$ 는 면의 절점을 연 결하는 방향으로 설정하였다.

Fig. 3에서와 같이 설정된 좌표계로부터 면 중심에서 물 리량의 미분은 다음과 같이 표현된다.

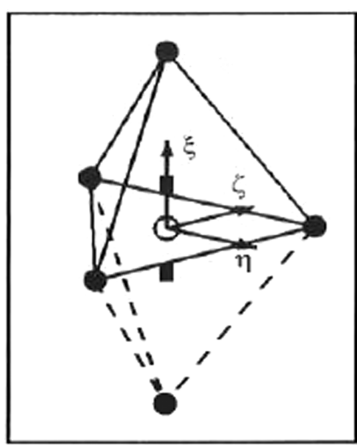

Fig. 3. Local axis system placed at the face.

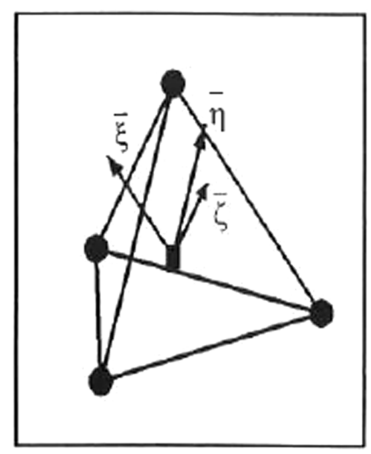

Fig. 4. Local axis system placed at the center of cell.
$Q_{x}=Q_{\xi} \xi_{x}+Q_{\eta} \eta_{x}+Q_{\zeta} \zeta_{x}$

$Q_{y}=Q_{\xi} \xi_{y}+Q_{\eta} \eta_{y}+Q_{\zeta} \zeta_{y}$

$Q_{z}=Q_{\xi} \xi_{z}+Q_{\eta} \eta_{z}+Q_{\zeta} \zeta_{z}$

Fig. 4에는 셀 중심에 위치한 국부좌표계를 도시하였는데 각 면의 중심점들을 연결하는 방향으로 좌표축을 설정하였다.

Fig. 4에서와 같은 국부좌표계를 이용하면 셀 중심에서 물리량의 미분은 다음과 같다.

$Q_{x}=Q_{\bar{\xi}} \overline{\xi_{x}}+Q_{\bar{\eta}} \overline{\eta_{x}}+Q_{\bar{\zeta}} \overline{\zeta_{x}}$

$Q_{y}=Q_{\bar{\xi}} \overline{\xi_{y}}+Q_{\eta} \overline{\eta_{y}}+Q_{\bar{\zeta}} \overline{\zeta_{y}}$

$Q_{z}=Q_{\bar{\xi}} \overline{\xi_{z}}+Q_{\eta} \overline{\eta_{z}}+Q_{\bar{\zeta}} \overline{\zeta_{z}}$

식 (17),(18)에서와 같이 물리량의 일차 미분은 면의 중심 점과 셀의 중심점에서 계산되며, 면 중심에서 물리량의 이 차미분은 셀 중심에서의 1 차 미분값을 차분하여 구하게 된 다. 인접한 셀의 면에 정의된 물리량으로 이차미분이 이루 어지도록 하여 중심차분이 중복되지 않도록 함으로써 이차 차분시 발생할 수 있는 지그재그 현상을 방지하도록 하였 다. 한편 대류항 계산시 상류 차분은 속도 방향을 고려한 면에서의 미분값과 셀 중심에서의 미분값을 이용하여 처리 하였다.

\section{Results and Discussion}

\section{1. 난류영역에서 속도경사 계산}

Fig. 1은 일반적으로 실험실에서 Jar 테스트할 경우 많이 사용하는 장치와 회전수에 따른 속도경사, $\mathrm{G}$ 값을 수온에 따라 도시한 것이다. 그러나 최대 회전수가 $300 \mathrm{rpm}$ 이기 때문에 그 이상의 $\mathrm{G}$ 값에서 실험하고자 할 때 어려움이 있고, 단순히 회전수를 연장하여 사용할 수밖에 없다. 그러나 급 속교반은 임펠라를 통해 가해지는 동력으로 난류 $\left(R_{e}>10,000\right)$ 를 유지한 상태에서 화학약품을 물속으로 확산시키는 공정 이다. 즉, 난류영역에서 $\mathrm{G}$ 값을 산정해야 되고, 식 (2)와 식 (10)을 이용하여 식 (19)와 같은 관계식을 얻을 수 있다. 


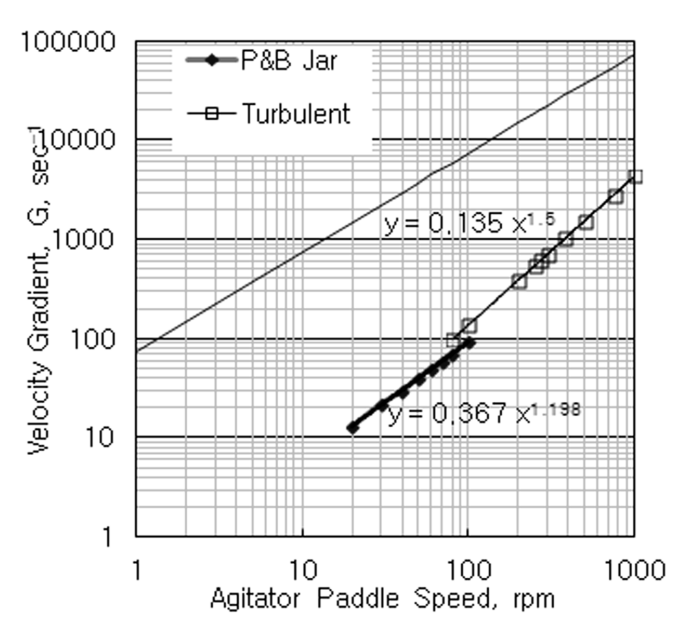

Fig. 5. Evaluation of $\mathrm{G}$ values as a function of rotating speed at transient and turbulent range and $G$ values suggested by Phips \& Bird Co. $\left(20^{\circ} \mathrm{C}\right.$, Density $998.2 \mathrm{~kg} / \mathrm{m}^{3}$; Dyamic Viscosity $1.002 \times 10^{3} \mathrm{~N} \cdot \mathrm{s} / \mathrm{m}^{3}$ )

$\bar{G}=\left(\frac{N_{p} \rho N^{3} D^{5}}{\mu V}\right)^{1 / 2}$

Fig. 5는 회전속도에 따른 레이놀드수(식 (3))와 속도경사 (식 (19))를 계산하여 도시한 것이다. 식 (19)와 같이 G값 은 회전속도, $\mathrm{N}$ 의 1.5 승에 비례하여 중가한다. 굵은 실선은 Fig. 5에서 제시된 임펠라 회전속도에 따른 $\mathrm{G}$ 값이고, 그 추세선식을 도시한 것이다. 또한 문헌에 따른면 레이놀드수 100 이상부터 난류영역으로 여기며 그 이하는 천이구역으로 칭하는 것으로 보고 되고 있다(Amirtharajah et al., 1991), 따라서, 식 (3)으로부터 계산된 레이놀드수를 기준으로 볼 때, $100 \mathrm{rpm}$ 이하의 구간에서는 충분히 난류가 발생하지 않 기 때문에 급속교반 영역으로 보기 어렵고, 식 (19)를 사용 하여 $\mathrm{G}$ 값을 계산하면 오차가 발생할 수 있다.

Fig. 1에서 제시된 G값은 Fig. 5와 같이 회전속도의 1.2 승에 비례하는 것으로 나타났다. Fig. 5에 도시된 바와 같 이 완전 난류영역에서 계산된 것과 차이가 있다. 이는 동 력수(식 (2))를 바탕으로 $\mathrm{G}$ 값을 계산한 것이 아니고, 천이 영역에서 축에 걸리는 토크를 실측하여 산정한 것으로 추 정된다. 상용되는 Jar 테스트 장치는 급속교반과 완속교반 실험을 병행해야 하기 때문에 $300 \mathrm{rpm}$ 이하의 영역에 대한 $\mathrm{G}$ 값을 제공해 주고 있다. 그러나 이 영역은 난류와 천이영 역을 동시에 포함하고 있어 급속교반공정(난류영역)에 사용 할 경우 정확한 $\mathrm{G}$ 값을 산출할 수 없다. 반응조에서 층류는 $10 \mathrm{rpm}\left(\left(R_{e}<500\right)\right.$ 이하일 때이므로 완속교반 범위에서 벗어 나기 때문에 고려 대상에서 제외할 경우, Fig. 1에 제공된 $\mathrm{G}$ 값은 난류영역과 천이영역에 걸쳐 있기 때문에 천이영역 인 $100 \mathrm{rpm}$ 이하일 때 적용하는 것이 좋고, 그 이상의 회전 속도(난류영역)에서는 식 (19)에 의해 계산된 G값을 사용하 는 것이 보다 정확한 결과를 얻을 수 있을 것이다. 결론적 으로 말해, 일상적으로 사용하는 Jar 실험(Fig. 1)에서 회전 속도에 따른 $\mathrm{G}$ 값을 산정할 때 임펠라 회전수에 따라 Fig. 5 와 같은 관계를 활용하는 것이 보다 정확한 결과를 얻을
수 있고, 특히, 회전수가 높은 고강도 교반에서는 큰 오차 를 줄일 수 있을 것이다.

\section{2. 이론적 총물질전달시간 산출}

총물질전달시간은 주입한 화학물질이 반응물질과 접촉하 는데 소요되는 시간을 의미하며, 식 (13)과 같이 완전혼합 시간과 분자확산시간의 합으로부터 얻을 수 있다. 순환시간 은 식 (4)와 같이 회전속도와 역비례관계가 있으며, Fig. 1과 같은 Jar를 이용하여 실험할 경우 Fig. 6에 도시된 식 $(y=$ $\left.301.3 \mathrm{x}^{-1}\right)$ 으로 산출할 수 있다. 또한 식 (5)로부터 완전혼합 시간은 순환시간의 3 배로 가정하여 산출하였고, 물질확산시 간은 식 (6)과 식 (9)로부터 G값의 역수에 비례하기 때문에 회전속도의 1.5 승에 반비례하는 관계에 있다. 그러므로 물 질확산시간은 Fig. 4와 같이 회전속도의 함수로 표시가능하 며, $\mathrm{G}$ 값이 $1,000 \mathrm{sec}^{-1}$ 일 때 약 1 초정도의 값을 갖는다(식 (11)). 회전속도가 증가하면서 eddy 크기가 작아짐에 따라 물질확산시간이 감소하는 비율이 완전혼합시간이 감소하는 비율보다 크기 때문에 빠른 회전속도에서는 물질확산시간 보다 완전혼합시간이 총물질전달시간을 결정하는 인자로 작용한다.

총물질전달시간이 1 초이하가 되기 위해서는 Fig. 5 에서와 같이 $1,000 \mathrm{rpm}$ 이상 고강도로 교반시켜야 되며, 이때의 $\mathrm{G}$ 값은 약 $4,300 \mathrm{sec}^{-1}$ 이다. 그러나 $600 \mathrm{rpm}$ 이상 회전시킬 경 우 Jar의 수표면이 심하게 요동쳐서 많은 공기가 유입될 뿐 아니라 Jar 밖으로 물이 튀어 넘치기 때문에 Jar에서 실 험 가능한 범위는 아니다. 그러므로 이러한 고강도의 교반 은 다양한 관내혼합방법을 사용하야 한다. 급속교반조건으 로 문헌에서 제시하는 $\mathrm{G} \cdot \mathrm{t}$ 값 1000 (일반적으로 $\mathrm{G}=1,000$ $\mathrm{sec}^{-1}, \mathrm{t}=1 \mathrm{sec}$ )은 물질확산시간 만(식 (11))을 고려한 값이다. 이때의 교반속도는 약 $400 \mathrm{rpm}$ 이며, 물질확산시간은 주입 한 화학약품이 반응조 전체에 완전히 혼합된 것을 전제로 계산된 값이므로 총물질전달시간과는 차이가 있다. 실질적 으로 화학약품과 반응물질이 1 초이내에 접촉하기 위해서는

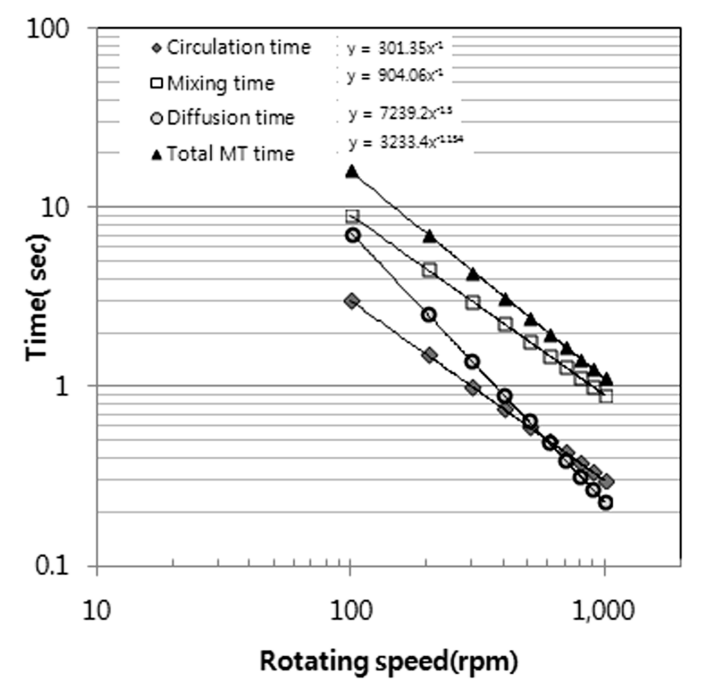

Fig. 6. Various mass transfer times at different rotating speed of paddle. 
총물질전달시간이 1 초가 되는 교반속도 $1,000 \mathrm{rpm}$ 일 때이고, $400 \mathrm{rpm}$ 이상의 고강도 교반조건일 때는 물질확산시간보다 완전혼합시간이 물질전달시간을 결정하게 된다.

\section{3. 실험에 의한 완전혼합시간 산출}

완전혼합시간은 다양한 교반조건에서 주입한 추적자가 완전히 혼합되는 시간을 측정하여 실험적으로 결정할 수 있다. Fig. 7은 2L Jar에 회전속도가 108에서 $480 \mathrm{rpm}$ 범위 로 교반되고 있는 각 $\mathrm{Jar}$ 에 불소를 주입하고, 교반시간에 따라 $\mathrm{Jar}$ 하단에 있는 밸브에서 시료를 채취하여 불소의 농도를 측정한 결과이다. 주입한 불소가 완전히 혼합될 경 우 불소의 농도는 약 $1.5 \mathrm{mg} / \mathrm{L}$ 이었으며, Fig. 7 과 같이 15 초 이상 교반할 경우 모든 $\mathrm{Jar}$ 에서 평형농도에 도달하였다. $108 \mathrm{rpm}$ 에서 주입한 불소가 완전히 혼합되는 시간은 약 8.9 초 정도 소요되었으며, 회전속도가 증가할수록 완전혼합 시간이 감소하여 $480 \mathrm{rpm}$ 에서는 약 3 초정도가 소요되었다. Table 1은 Fig. 6 결과로부터 도출한 회전속도에 따른 완전 혼합시간 $\left(t_{M}\right)$ 과 식 (5) 및 (6)에 의해 계산한 완전혼합시간 및 eddy내 확산시간 $\left(t_{D}\right)$ 과 식 (12)에 의해 계산한 총물질전 달시간 $\left(t_{M T}\right)$ 을 정리한 것이다.

실험에서 산출된 값과 계산에 의해 산출된 완전혼합시간 은 $108 \mathrm{rpm}$ 에서는 각각 8.9초와 8.4초로 서로 유사한 값을 갖다가 교반속도가 증가할수록 점차 산출된 값의 차이가

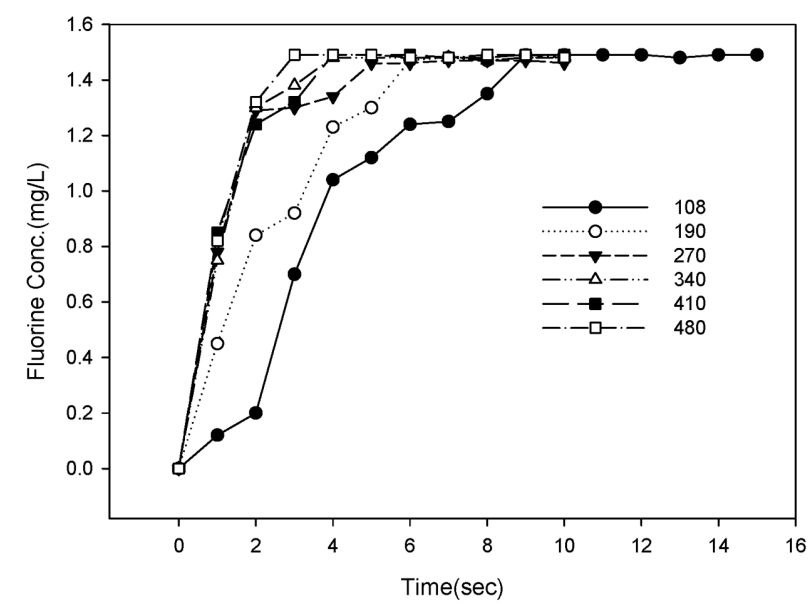

Fig. 7. Concentrations of Fluorine as a function of mixing time at different rotating speed (rpm).

Table 1. Calculated total mass transport time $\left(t_{M T}\right)$ with experimental mixing time $\left(t_{M}\right)$ at various rotating speed in a $2 \mathrm{~L}$ Jar

\begin{tabular}{c|c|c|c|c}
\hline \multirow{2}{*}{$\mathrm{rpm}$} & \multicolumn{2}{|c|}{$t_{M}(\mathrm{sec})$} & \multirow{2}{*}{$t_{D}(\mathrm{sec})$} & \multirow{2}{*}{$t_{M T}(\mathrm{sec})$} \\
\cline { 2 - 3 } & Experimental & Calculated & & \\
\hline \hline 108 & 8.9 & 8.4 & 6.4 & 14.8 \\
\hline 190 & 6.0 & 4.7 & 2.8 & 7.5 \\
\hline 270 & 5.0 & 3.4 & 1.6 & 5.0 \\
\hline 340 & 4.0 & 2.6 & 1.2 & 3.8 \\
\hline 410 & 3.6 & 2.2 & 0.9 & 3.1 \\
\hline 480 & 3.0 & 1.9 & 0.7 & 2.6 \\
\hline
\end{tabular}

$t_{M}$ : complete mixing time, $t_{D}:$ diffusion time, $t_{M T}:$ total mass transport time

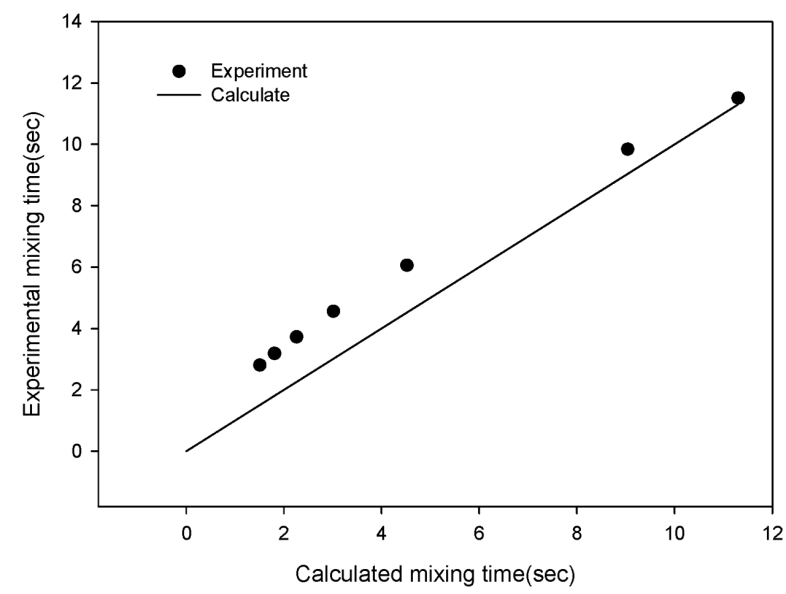

Fig. 8. Calculated and experimental mixing time.

발생하는 것으로 나타났다. $480 \mathrm{rpm}$ 에서는 실험값이 3 초로 계산값 1.9 초보다 길었으며, 교반속도에 따른 계산(calculated) 에 의하여 산출한 완전혼합시간과 추적자실험(experimental) 을 통하여 얻은 완전혼합시간을 도시하면 Fig. 8과 같다. 이 러한 차이는 고강도 교반일수록 자유수면의 왜곡도가 심해 지고, 동력의 일정 부분이 열이나 기타 요인에 의해 소모 되기 때문으로 생각된다. 따라서, 다른 연구자들 중에서도 Jar-test에 의해서 결정된 최적값이 $\mathrm{G}$ 값은 같더라도 다른 기하학적 상사성이 다른 형태의 현장에서도 최적이 되기에 는 무리가 있다고 보고하였다(Clark, 1985; Cleasby, 1984).

Fig. 9는 교반속도에 따른 총물질전달시간을 각 성분별로 도시한 것이다. 교반속도가 증가할수록 총물질전달속도는 급격히 감소하며, 특히, 확산시간이 큰 폭으로 감소함을 알 수 있다. 일부 문헌(Kawamura and Trussell, 1991)에서 최 적의 급속교반조건으로 $\mathrm{G}$ 가 $1,000 \mathrm{sec}^{-1}$ 일 때 교반시간 1 초 를 제시하고 있으나, 이는 생성된 eddy 내로의 분자확산시 간만을 고려한 것이기 때문에 주입한 화학약품의 완전혼합 시간을 더할 경우 실질적인 교반시간은 더 길어져야 한다.

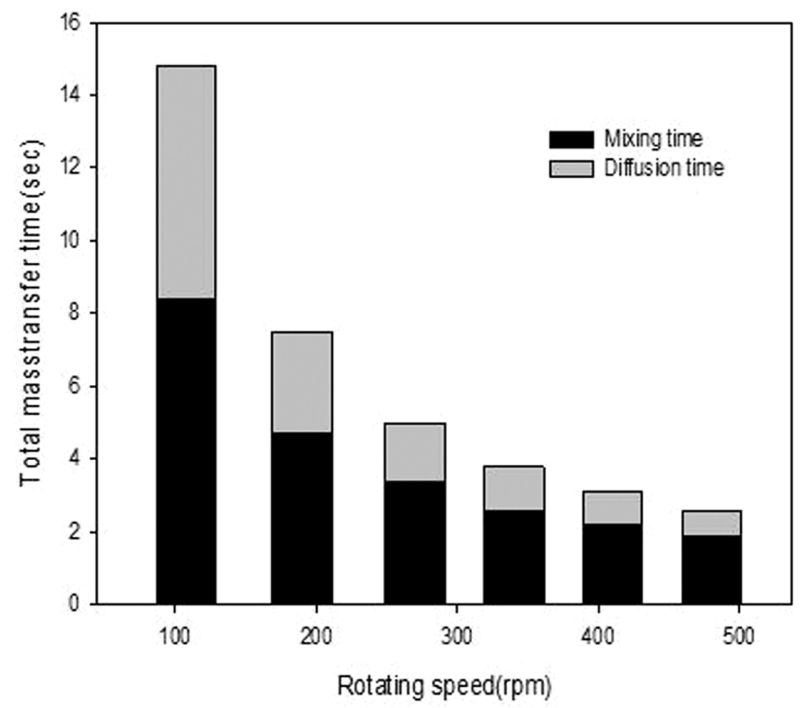

Fig. 9. Component of total mass transfer time at different rotating speed. 
완전혼합시간은 실험을 통해 화학물질이 균일하게 되는 시 간을 측정한 것이기 때문에 실험조건 및 수온과 같은 환경 인자에 따라 달라질 수 있다. 그러나 Fig. 6과 같이 회전속 도 증가에 따른 완전혼합시간 감소 폭이 더 작기 때문에 교반속도가 클수록 완전혼합시간이 총물질전달시간을 좌우 하게 된다.

결론적으로 회전속도가 $100 \mathrm{rpm}$ 이상일 때, 즉 난류영역 에서 총물질전달시간은 회전속도가 클수록 물질확산시간보 다 완전혼합시간에 좌우되며, 1 초이내의 짧은 화학반응시간 을 고려할 때, 교반에 의한 완전혼합시간이 반응기 내 체 류시간을 결정하는 중요한 인자임을 알 수 있다. 그러나 완전혼합시간은 약품주입위치나 방법에 따라 다를 수 있고, 수온과 같은 환경인자에 따라서도 바뀔 수 있기 때문에 이 를 최적화 시킬 수 있는 방법을 고안할 필요가 있다.

\section{4. $\mathrm{CFD}$ 를 이용한 총물질전달시간 산출}

Fig. 10은 $50 \mathrm{rpm}$ 으로 회전시킬 경우 임펠라 주변의 속도 분포를 도시한 것이다. $50 \mathrm{rpm}$ 일 때 임펠라 선단의 유속이 임펠라 선단속도의 $75 \%$ 라고 가정할 경우 $0.15 \mathrm{~m} / \mathrm{s}$ 이다. 임 펠라 주변의 유속분포는 $0.14-0.12 \mathrm{~m} / \mathrm{s}$ 의 범위로 이론적인 최대값과 유사한 값이며, 임펠라를 벗어나면서 유속은 급속 하게 감소하고 있고, 임펠라축 부분의 유속이 가장 작은 것으로 나타났다. 이러한 속도차로 인하여 물질전달이 가능 하게 되며, 공간상의 속도차 크기가 물질전달속도를 결정하 게 된다. 단면이 사각형인 Jar는 임펠라 회전에 의한 공간 상의 속도차가 크게 발생하기 때문에 약품분산을 위한 급 속교반공정에 많이 사용되고 있다. Fig. 11 은 추적자를 $\mathrm{Jar}$ 의 수표면위에 주입한 후 교반시간이 0.75 초일 때 추적자의 농도분포를 도시한 것이다. 농도의 단위는 주입한 스칼라 (CFD에서 농도 변화에 대한 표기법으로 무차원의 값)양에 대한 분산에 따라 희석되는 비율로 완전히 분산되었을 경 우 농도값은 약 0.001381 이다. 추적자 주입 후 주입지점으로 부터 공간적으로 확산되어 가는 과정을 도식적으로 보여주고 있으며, 이론적으로 모든 위치에서 농도 값이 0.001381 이 될 경우 완전혼합이 완료된 시간이 된다. 그러나 $\mathrm{Jar}$ 내 모든 점에서 농도 값이 0.001381 이 된 경우는 이미 완전혼합이 종료된 시점이므로, Fig. 2에 도시된 8점에서 표준농도 (normal concentration, 그 지점의 농도 값을 0.001381 로 나 눈 값)값의 평균이 표준농도(1.0)와 $0.1 \%$ 오차내로 분산되는

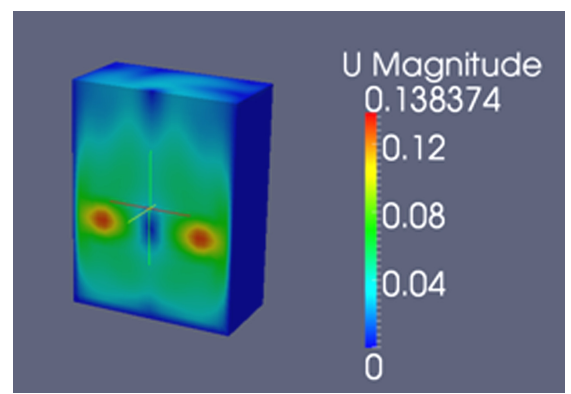

Fig. 10. Velocity profiles $(\mathrm{m} / \mathrm{s})$ in a cross section of jar at $50 \mathrm{rpm}$.
시간을 완전혼합시간으로 결정하였다.

Fig. 12 A-E는 교반속도별로 교반시간에 따른 위의 Jar내 8지점에서 추적자의 표준농도 값을 도시한 것이다. 추적자 를 수표면에 주입하였기 때문에 위의 지점은 표준농도보다 큰 값을 갖고, 아래 지점에서는 표준농도 값보다 작은 값 으로 출발하여 교반시간이 지남에 따라 표준농도 값인 1.0 에 접근하는 경향을 보이고 있다. 교반속도가 $50 \mathrm{rpm}$ 으로 작을 때에는 지점별 표준농도의 편차가 크고, 교반속도가 중가할수록 지점별 표준농도 값의 편차가 감소함과 동시에 짧은 시간 내에 표준농도 값에 근접하는 것을 알 수 있다. $600 \mathrm{rpm}$ 에서는 3 초이내에 완전혼합시간이 종료되는 것으로 나타났다. $0.1 \%$ 허용오차내로 표준농도 값에 근접한 교반 시간을 추적자가 완전히 분산된 시간으로 산정한 결과는 Table 2과 같다. Table 2은 $\mathrm{CFD}$ 로 산출한 완전혼합시간과 함께 Table 1에 정리된 계산 값 및 실험결과 도출한 값을 동시에 표기한 것이다. $\mathrm{CFD}$ 로 산출한 완전혼합시간은 Table 2와 같이 계산결과 보다는 실험에서 도출한 결과 값 과 유사한 경향을 보이고 있다. 짧은 완전혼합시간, 즉 교 반속도가 클 때는 실험값이나 CFD 산출값이 계산값 보다 크고, 완전혼합시간이 10 초 이상 길 때, 특히, $50 \mathrm{rpm}$ 에서는 계산값에 비하여 $\mathrm{CDF}$ 산출값이 작은 것을 알 수 있다. 이 는 $100 \mathrm{rpm}$ 이하의 낮은 교반속도 값에서는 완전 난류영역 이 아니라 천이영역에 해당되기 때문에 난류영역에 적용된 식으로 계산된 값(식 (4),(5))은 실제의 총물질전달시간과 차이가 있기 때문으로 생각된다. 본 실험결과 $\mathrm{CFD}$ 에 의한 급속교반조의 수리학적 해석으로 확산 실험결과를 정확하 게 모의할 수 있는 것으로 나타났으며, 복잡한 반응조 내 물질의 확산과정을 해석하는 데 유용하게 활용될 수 있을 것으로 판단된다.

\section{Conclusion}

본 논문에서는 완전난류영역에서 산출된 패들을 통해 전 달되는 동력값을 이용하여 $\mathrm{G}$ 값을 산출하였고, 기존에 폭 넓게 사용되어 온 $\mathrm{G}$ 값과 비교 및 추적자 실험과 $\mathrm{CFD}$ 를 활용하여 완전혼합시간을 도출하여 계산 값과 또한 비교하 였으며, 이를 이용하여 회전속도에 따른 총물질전달시간을 산출하였다.

1) 표준 Jar에서 패들의 회전속도가 $100 \mathrm{rpm}$ 이상부터 레이

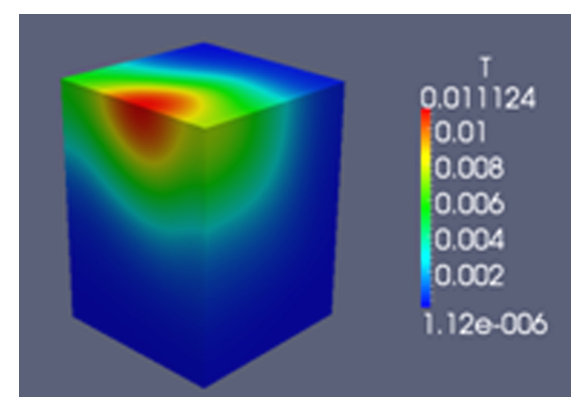

Fig. 11. Dispersion of the tracer throughout jar at $50 \mathrm{rpm}$ after $0.75 \mathrm{sec}$. 


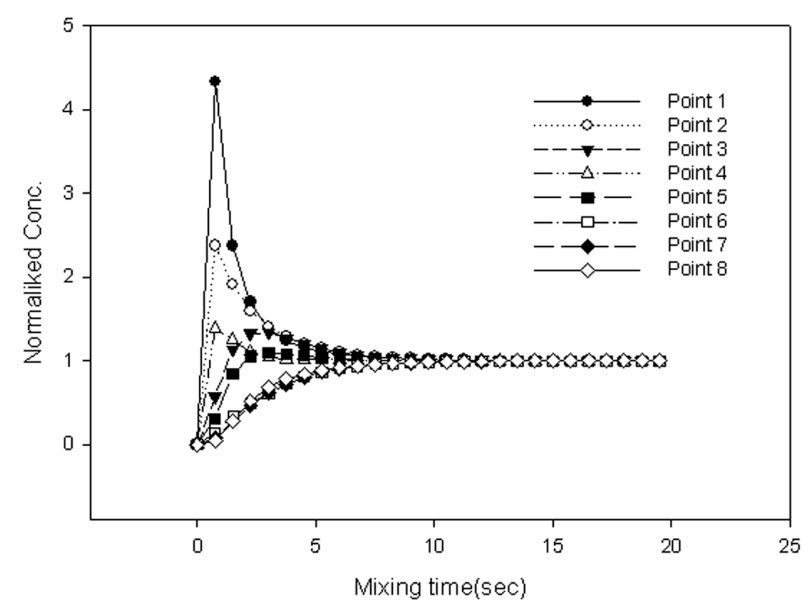

A:50rpm

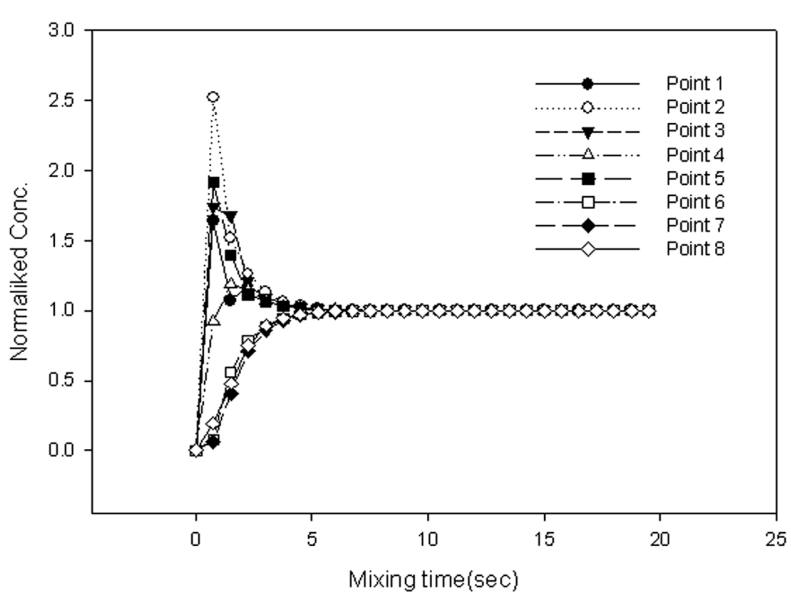

C:200rpm

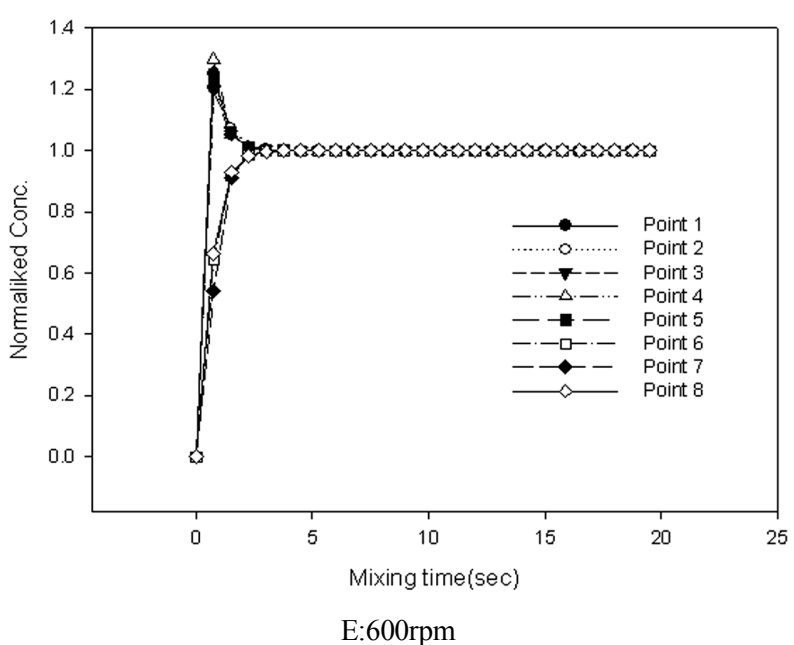

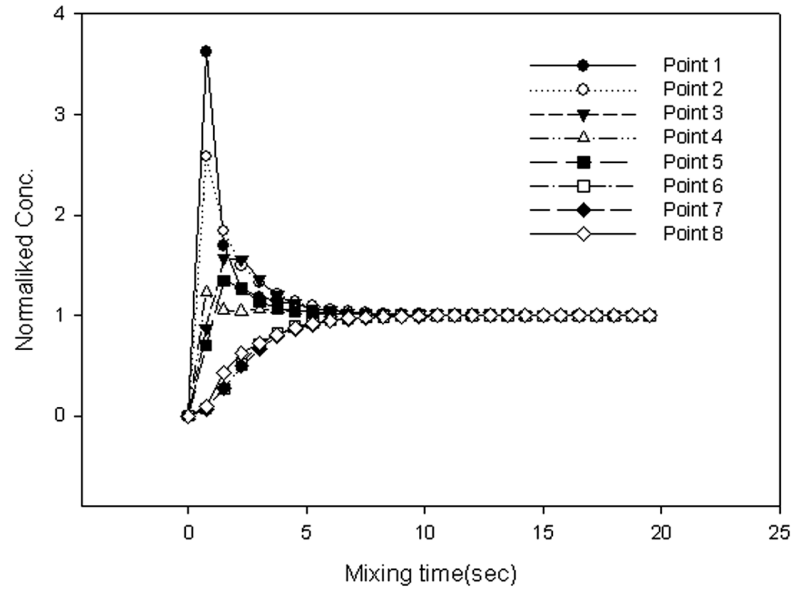

B:100rpm

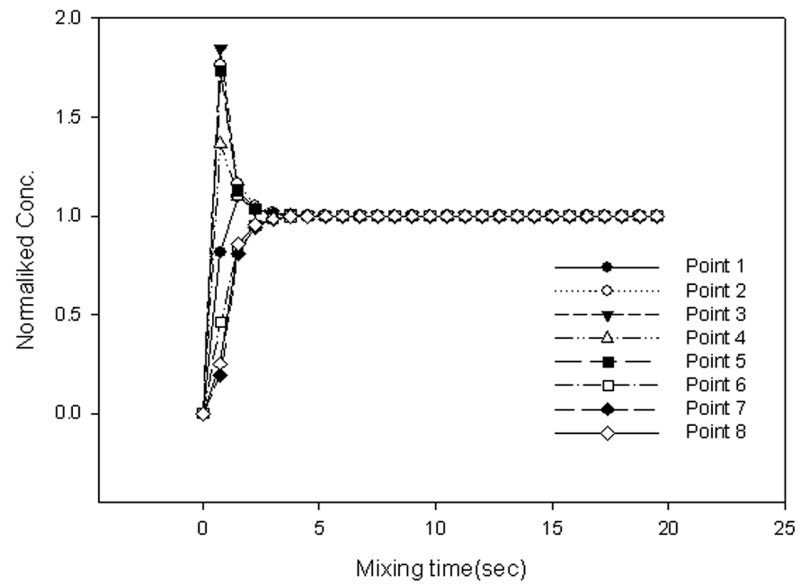

D:400rpm

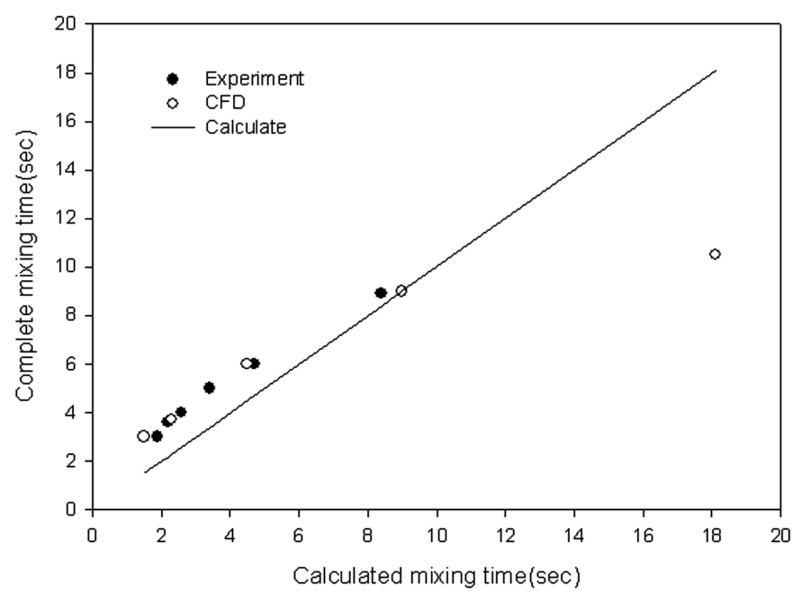

F:Complete mixing time

Fig. 12. Normalized conc. of tracer simulated with Water-CFD at various sampling points in jar as a function of mixing time. A: at $50 \mathrm{rpm}, \mathrm{B}: 100 \mathrm{rpm}, \mathrm{C}: 200 \mathrm{rpm}, \mathrm{D}: 400 \mathrm{rpm}, \mathrm{E}: 600 \mathrm{rpm}, \mathrm{F}$ : Calculated vs. simulated mixing time

놀드수가 10,000 이상인 난류영역이고, 층류는 $10 \mathrm{rpm}$ 이 하의 영역에서 발생하였다. $10-100 \mathrm{rpm}$ 사이의 영역은 천 이영역으로 일반적으로 Jar 실험에 사용하는 범위였다.

2) 상용 Jar 실험장치 제조회사(Phips \& Bird Co.)에서 제 공하는 회전속도에 따른 $\mathrm{G}$ 값을 난류영역으로 연장할 경
우 동력수를 이용하여 산정한 $\mathrm{G}$ 값과 큰 차이를 보였다.

3) eddy 내 물질확산시간은 eddy 크기가 작아지면 회전속 도의 1.5 승에 반비례하여 감소하였다.

4) 완전혼합시간은 패들의 회전에 의한 펌핑수로 결정되며, 회전속도에 반비례하여 감소하였다. 따라서, 총물질전달 
Table 2. Comparison of simulated complete mixing times to those of calculated and experimentally evaluated

\begin{tabular}{c|c|c|c}
\hline \multirow{2}{*}{ rpm } & \multicolumn{3}{|c}{ Complete Mixnig time (sec) } \\
\cline { 2 - 4 } & Calculated & Experiment & CFD \\
\hline \hline 50 & 18.1 & -- & 10.5 \\
\hline 100 & 9.0 & -- & 9.0 \\
\hline 108 & 8.4 & 8.9 & -- \\
\hline 190 & 4.7 & 6.0 & -- \\
\hline 200 & 4.5 & -- & 6.0 \\
\hline 270 & 3.4 & 5.0 & -- \\
\hline 340 & 2.6 & 4.0 & -- \\
\hline 400 & 2.3 & -- & 3.7 \\
\hline 410 & 2.2 & 3.6 & -- \\
\hline 480 & 1.9 & 3.0 & -- \\
\hline 600 & 1.5 & -- & 3.0 \\
\hline
\end{tabular}

시간은 회전속도가 중가함에 따라 감소하게 되며, 1,000 $\mathrm{rpm}$ 일 때 1 초정도로 산정되었다.

5) 추적자를 이용하여 완전혼합시간을 산출한 결과 $108 \mathrm{rpm}$ 에서 8.9초, $480 \mathrm{rpm}$ 에서 3 초이었다. 회전속도가 큰 범위 에서 실험으로 도출한 완전혼합시간이 계산 값보다 큰 것으로 나타났다.

6) $\mathrm{CFD}$ 를 이용하여 산출한 완전혼합시간은 계산 값보다 실험결과 도출된 값과 비슷한 경향을 보였으며, 다양한 반응조내 교반현상을 파악하기 위한 실험을 효과적으로 대체할 수 있을 것으로 기대된다.

\section{Acknowledgement}

본 연구는 환경부 “차세대 에코이노베이션사업(글로벌탑 환경기술개발사업)"의 지원에 의해 수행되었으며 이에 감 사드립니다(GT-SWS-11-02-007-10).

\section{References}

Amirtharajah, A., Clark, M. M., and Trussell, R. R. (1991). Mixing in Coagulation and Flocculation, American Water
Works Association (USA), pp. 59.

Camp, T. R. (1968). Floc volume concentration, $A W W A$, 60, pp. 656-673.

Clark, M. M. (1985). Critique of Camp and Stein's RMS Velocity Gradient, Journal of Environmental Engineering, ASCE, 111(6), pp. 741-754.

Cleasby, J. Y. (1984). Is Velocity Gradient a Valid Turbulent Flocculation Parameter?, Journal of Environmental Engineering, ASCE, 100(5), pp. 875-897.

Han, M. and Lawler, D. F. (1992). The (Relative) Insignificance of $\mathrm{G}$ in Flocculation, Journal of American Water Works Association, 84(10), pp. 79-91.

Hudson, H. E. Jr. and Wolfner, J. P. (1967). Design of Mixing and Flocculation Basins, Journal of American Water Works Association, 59(10), pp. 1257-1268.

Jung, C. W., Kang, M. S., Chung, S. I., Shon, I. S., and Kang, L. S. (2003). A study of rapid mixing condition for improvement of water treatment process, 2003 Spring Conference of the Korean Society on Water Environment and Korean Society of Water and Wastewater, Korean Society on Water Environment and Korean Society of Water and Wastewater, pp. 53-56. [Korean Literature]

Jung, K. S., Jun, H. B., Park, S. M., and Park, N. B. (2006). Effects of Coagulant dose and Rapid Mixing Time on Particle Growth and Turbidity Removal, 2006 Autumn Conference of the Korean Society on Water Environment and Korean Society of Water and Wastewater, Korean Society on Water Environment and Korean Society of Water and Wastewater, pp. 104-110. [Korean Literature]

Kawarnura, S. (1976). Consideration in improving flocculation, Journal of American Water Works Association, 68, pp. 328-336.

Kawamura, S. and Trussell, R. (1991). Main Features of Large Water Treatment Plants in Japan, Journal of AWWA, 74(3), pp. $148-159$.

Kim, S. H., Yoon, D. S., and Moon, B. H. (2011). Evaluation of effect of rapid mixing intensity on chemical phosphorus removal using Al hydrolysis speciation, Journal of Korean Society of Water and Wastewater, 25(3), pp. 367-373. [Korean Literature]

Vrale, L. and Jorden, R. N. (1971). Rapid mixing in water treatment, Journal of American Water Works Association, 63, pp. $52-58$. 